ISSN: 2146-3042

DOI: $10.25095 /$ mufad.536020

\title{
TFRS 15 ve TMS 21 Kapsamında Forfaiting Muhasebesi
}

\author{
Birsel SABUNCU*
}

\begin{abstract}
$\ddot{O Z Z T}$
Forfaiting işlemi ile firmalara, orta ve uzun vadeli alacaklarının kısa sürede tahsil edilmesi sayesinde likiditelerini arttırabilme imkanı sağlanmaktadır. Forfaiting alternatif bir finansman tekniği olarak piyasada rekabet firsatı oluşturmaktadır.

Bu çalışmada alternatif bir finansman tekniği olan forfaiting işlemlerinin piyasa rekabetinde firmalara să̆ladı̆̆ avantajların önemi vurgulanmış, Türkiye Finansal Raporlama Standardı (TFRS) 15 Müşteri Sözleşmelerinden Hasılat standardı ve Türkiye Muhasebe Standardı (TMS) 21 Kur Değişiminin Etkileri standardı çerçevesinde forfaiting sözleşmelerindeki tarafların muhasebe esasları üzerinde durulmuş, yapılması gereken muhasebe kayıtlarına ilişkin örnek uygulamalara yer verilerek forfaiting işlemlerinin tanınırlığı için literatüre katkı săglamak hedeflenmiştir.

Forfaiting işlemlerinde sözleşmede yer alan işlem bedelinin hasılat olarak muhasebeleştirilmesi, faiz ve benzeri giderlerin doğduğu dönemde gider olarak, gelirlerin de doğduğu dönemde gelir olarak muhasebe kayıtlarına alınması söz konusudur. Yabancı paralı işlemlerin işlem tarihindeki spot kur üzerinden geçerli para birimine çevrilerek muhasebeleştirildiği, finansal tabloların çevriminde ise, varlık ve yükümlülüklerin raporlama tarihindeki spot kur üzerinden çevrildiği gözlemlenmektedir.
\end{abstract}

Anahtar Kelimeler: Forfaiting işlemleri, TFRS 15, TMS 21, muhasebe

JEL Sınıflandırması: M40, M41

\section{Forfaiting Accounting In The Scope Of TFRS 15 and TAS 21}

\section{ABSTRACT}

Thanks to the forfaiting process, it is possible to increase liquidity through the collection of medium and long term receivables in short time. Forfaiting is an opportunity for competition in the market as an alternative financing technique.

In this study, the advantages of the forfaiting transactions, which are an alternative financing technique, are emphasized in the market competition. The accounting principles of the parties in the forfaiting contracts are emphasized in the framework of the Turkish Financial Reporting Standards (TFRS) 15 Revenue from Contracts with Customers and Turkish Accounting Standard (TAS) 21 The Effects of Changes in Foreign Exchange Rate Standard in order to contribute to the literature.

In forfaiting transactions, the transaction amount recorded in the agreement is recognized as revenue, interest and similar expenses are recorded as expenses in the period in which they are incurred and income is recorded as income in the accounting period. Foreign currency transactions are accounted for using the spot exchange rate at the transaction date and the translation of the financial statements is carried out over the spot rate at the reporting date of the assetsand liabilities.

Keywords: Forfaiting operating, TFRS 15, TMS 21, accountinG

Jel Classification: M40, M41

\footnotetext{
${ }^{*}$ Dr. Öğr. Üyesi, Pamukkale Üniversitesi, Honaz Meslek Yüksekokulu, bsabuncu@pau.edu.tr, ORCID ID: 0000-0002-3785-5446
} 


\section{GíRiş}

Forfaiting tekniğinin çıkış noktası dış ticaret işlemlerinde satıcıların mal bedelini peşin talep etmelerine rağmen alıcıların vadeli mal alımında ısrarcı olmalarıdır. Bankalar bu soruna çözüm olarak ihracatçıya nakit sağlarken ithalatçı için de kredi olanağı sağlayan bir teknik geliştirmişlerdir. Forfaiting olarak adlandırılan bu teknikte ihracatçı bir taraftan alacağını hemen tahsil ederken diğer taraftan satışla ilgili her türlü riskten de kurtulmaktadır.

Ticari hayatta değişen rekabet koşulları ile birlikte çeşitli finans teknikleri de gelişmiştir ve bu tekniklerden biri de forfaiting olmuştur. Forfaiting piyasalarda artan uluslararası rekabet nedeniyle uzun vadelerle mal satışları sonucunda ortaya çıkmıştır. İhracatçılar alacaklarını tahsilde güçlüklere uğramış, faiz ve kur riski gibi ek risklerle karşılaşmışlardır. Bu riskleri kontrol edebilmek adına forfaiting işlemleri gündeme gelmiştir.

Forfaiting, vadeli mal ve hizmet ihracatı nedeniyle gerçekleşen alacağın bir ödeme planı çerçevesinde bir banka veya finans kuruluşuna rücu edilemez şekilde satılmasıdır. Alacaklar forfaitere satıldiktan sonra senetlerin tahsil edilememesi gibi herhangi bir risk söz konusu olduğunda forfaiter bunu ihracatçıya rücu edememekte bütün riski üstlenmektedir. Ancak forfaitinge konu olan mal veya hizmet ihracatçının hatasından kaynaklanan kusur nedeniyle iade edilmişse bundan ihracatçı sorumlu olmaktadır. Gerçek anlamda forfaiting işlemi ihracatçının mal veya hizmeti satmadan önce forfaitere başvurup onun tarafından kabul edilmesiyle başlamakta ve satış işlemi gerçekleştikten sonra söz konusu senetleri belirlenmiş olan oranda forfaitere iskonto ettirerek nakit sağlanması şeklinde gerçekleşmektedir.

Forfaiting, ülkemizde finansman ihtiyacını karşılamasından dolayı dünyadaki kadar yaygın olmayıp çok daha az uygulanmaktadır. Alternatif finansman tekniklerinden olan forfaiting işlemlerinin işleyişinin açıklanması gerekmektedir. Ülkemizde forfaiting işleminde forfaiter görevinde olanlar genellikle bankalar veya finans kuruluşları olmaktadır. Forfaiting ile ilgili literatür taraması sonucunda aşağıdaki çalışmaların varlığı söz konusudur;

Dikmen (1992), "Forfaiting Risk ve Riskten Korunma" adlı çalışmalarında risk açısından forfaiting işlemleri değerlendirilmektedir.

Özdemir (2005), "Dış Ticaret Finansman Tekniklerinden Faktoring ve Forfaiting İşlemleri” çalışmalarında bu yöntemlerin ekonomiye katkıları ile ilgili genel bir değerlendirme yapılmıştır. Fakat muhasebeleştirme boyutuna değinilmemiştir.

M. Vefa Toroslu (2011), "Hukuksal ve Finansal Açıdan Forfaiting" adlı çalışmalarında hukuksal, vergisel ve muhasebesel olarak forfaitingi açıklamaktadırlar.

Aygün (2014) "TMS 18 Hasılat ve TMS 2 stoklar standartlarına göre forfaiting işlemleri ve muhasebeleştirilmesi” adlı çalışmalarında ilgili standartlara göre dönem sonlarında yapılan birtakım uygulamaların gereksiz olduğunu belirtmektedir.

Ülkeler arasındaki sınırların kalkması, rekabetin artması, ticaretin genişlemesi ile küreselleşen ekonomide firmaların finansal raporlarının doğru biçimde değerlendirilebilmesi, karşılaştırılabilmesi için her alanda olduğu gibi muhasebe alanında da standartlaşmaya ihtiyaç duyulmuştur. Bu durum birçok ülkede ve ülkemizde de kabul gören Uluslararası Finansal 
Raporlama Standartlarını oluşturmuştur ve ülkemizde de Türkçeye çevrilerek Türkiye Muhasebe Standartları/Türkiye Finansal Raporlama Standartları (TMS/TFRS) olarak yayımlanmıştır. Standartlar yürürlüğe girmeden önce Tekdüzen Muhasebe Sistemi doğrultusunda gerçekleştirilen forfaiting işlemlerine ilişkin muhasebe kayıtları günümüzde yürürlükteki standartlar çerçevesinde gerçekleştirilmektedir.

Bu çalışmada, "TFRS 15 Müşteri Sözleşmelerinden Hasılat" standardı ve "TMS 21 Kur Değişimini Etkileri” standardı usul ve esasları çerçevesinde uluslararası ticarette orta ve uzun vadeli alternatif bir finansman tekniği olan forfaiting işlemlerinin ölçüm ve muhasebe esaslarını ele alarak, forfaiting işlemlerinin ülkemizdeki firmaların piyasalardaki rekabetinde kullanılırlığını, tanınırlığını arttırmaktır. İhracat yapan firmaların alacaklarını daha kısa sürede tahsiline imkan veren, likidite sağlayan, nakit akışını kolaylaştıran kısa sürede fon yaratılmasını sağlayan bu teknikten yararlanan firma ile söz konusu alacakları satın alan forfaiter arasındaki forfaiting sözleşmelerine ilişkin muhasebeleştirme esasları açıklanarak literatüre katkı sağlamak hedeflenmektedir.

Forfating sözleşmelerinde ihracatçı ve forfaiter TFRS 15 ve TMS 21 standartları çerçevesinde ölçme ve muhasebeleştirmeyi gerçekleştirmektedir. Taraflardan biri olan forfaiter, forfaiting işlemlerinin muhasebeleştirilmesi ve finansal tabloların hazırlanmasında TMS/TFRS'ye tabi olup Bankacılık Düzenleme ve Denetleme Kurumu (BDDK) tarafindan yayımlanmış olan Tekdüzen Hesap Planı'ndan yararlanmaktadır. Alacaklarını satarak forfaiting hizmetini satın alan ihracatçı ise, muhasebe kayıtlarını Muhasebe Sistemi Uygulama Genel Tebliğ (MSUGT)'de bulunan Tekdüzen Hesap Planı doğrultusunda gerçekleştirilmektedir. Bu iki hesap planı arasında yapısal olarak farklılık söz konusudur. Forfaiter muhasebe kayıtlarını yabancı para ve Türk parası üzerinden gerçekleştirirken ihracatçı sadece yabancı para tutarını spot kur üzerinden Türk Parasına çevrilerek muhasebeleştirmektedir. TFRS 15 ve TMS 21 çerçevesinde muhasebe uygulamalarında taahhüt edilen mal ve hizmet müşterisine devredilerek borç yükümlüğü yerine getirildiğinde işlem bedeli vade farkları ayrıştırılarak hasılat olarak muhasebeleştirilmektedir. Yabancı paralı işlemler muhasebe kaydına alınırken işlem tarihindeki kur üzerinden geçerli para birimine çevrilmekte izleyen dönemlerde kapanış kurundan çevrilmekte ve kur farkları kâr/zararda muhasebeleştirilmektedir. Faiz ve benzeri giderler ile gelirler doğduğu dönemde gider ve gelir hesaplarında muhasebeleştirilmektedir.

\section{FORFAITING}

Forfaiting, mal ve hizmet ihracatı nedeniyle ortaya çıkan belli bir ödeme planı doğrultusunda gelecekte tahsil edilebilecek olan orta ve uzun vadeli alacakların vadeden önce satılarak tahsil edilmesidir. Teoride senetli veya senetsiz her türlü alacak forfaitinge konu olabilirse de uygulamada ilke olarak bütün ülkeler tarafindan yaygın şekilde kullanılan ve kabul edilen bono ve poliçeler forfaitinge konu olmaktadır. Forfaiting genellikle 6 aydan 10 yıla kadar olan vadeli dış ticaret alacakların finansmanında kullanılmaktadır (Gürsoy, 2005: 230). Forfaiting işlemlerinin en önemli özellikleri alacak ihracattan kaynaklanmalı, alacak aval ya da banka garantisine alınmış olmalı, senet borçlusu güvenilir olmalı ve forfaitinge konu satışlar kendisine rücu hakkı bulunmaksızın üçüncü kişilere devredilmelidir (Berk, 1999: 33). 
Forfaiting, mal ve hizmet ihracatından doğan belli bir ödeme planı içinde tahsil edilebilecek alacakların geri dönme hakkı olmaksızın forfaiter tarafindan satın alınmasıdır (Akgüç, 1998: 635). Forfaitingde, ihracatçı elindeki senet ya da poliçeyi anlaşmaya varılan bir oran üzerinden ve vadelerine göre iskontosu sonucu karşılığında nakit sağlamaktadır. Bu yöntemde sabit oranlı bir faiz ödemesi olduğundan ihracatçı gelecekte ortaya çıkabilecek faiz riskinden kurtulmaktadır. Forfaiting'de iskonto işlemi rücu edilememe esasına göre yapılmaktadır.

Forfaiting işleminde taraflar arasında yapılan sözleşmeye istinaden ihracatçı tarafından forfaitere belge ve bilgiler teslim edilmektedir. Forfaitere forfaiting miktarı, dövizin cinsi, vadesi, ihracatçının adı, ünvanı, adresi, ülkesi, ithalatçının adı, ünvanı, adresi, ülkesi, garantörün adı, ünvanı, adresi, ülkesi, ödeme araçları, garantiler, senet ya da poliçe tutarı, malların teslim tarihi, ithalatçının yapacağı geri ödeme tarihleri ve senetlerin ödeme yeri hakkında bilgi verilmektedir (Ceylan, 2003: 58).

Forfaiting işlemlerinde, yaygın bir kullanım alanı olan ve uluslararası bir standart bulunan bono ve poliçeler kullanılmaktadır. Poliçe, gösterilen lehdara vadede belirli bir tutarı ödeme emri veren senettir. Bono bir ödeme vaadi olup ithalatçı tarafindan düzenlenmektedir (Özdemir, 2005: 213). Bono ve poliçe dışında daha az kullanılmakla birlikte vadeli akreditifler ve banka teminat mektupları da kullanılabilmektedir. Vadeli akreditif ve banka teminat mektuplarının el değiştirmede sınırlı olması ve hukuki bir takım zorlukların olması bu tür araçların kullanımını sınırlamaktadır (Erdemol, 1992: 75).

Forfaiting işleminin çeşitli mal ve hizmetlerde uygulanması ile birlikte ödemedeki para birimi de çeşitlenmiştir. Forfaiting işlemi genellikle bütün dünya piyasasında yaygın olarak kullanılan Euro ve ABD Doları, İsviçre Frang1, Sterlin, İsveç kronu gibi konvertible paralar üzerinden yapılmaktadır (Ceylan, 2003: 54). Forfaitingde işlemlerinde kullanılacak paranın ülkeler arasında kolayca transfer edilebilir olması yeterlidir. Forfaitingde maliyetler forfaiterin fon maliyetine göre belirlendiğinden istikrarsız paralar üzerinde yapılacak anlaşmalarda riskin daha yüksek olması nedeniyle maliyetler yükseleceğinden forfaiting bedeli de artacaktır. Bu nedenle forfaitinge konu döviz cinsinin ihracata konu ülkeler arasında kolayca transfer edilebilir olması ve kabul edilir olması gerekmektedir.

Forfaiting işlemlerinde ihracatçı, ithalatçı, senedin ödeneceğini garanti eden garantör ve forfaiter olmak üzere dört taraf bulunmaktadır (Ceylan, 2003: 56). İhracatçı forfaiting işleminde alacak hakkını satan malı ihraç eden olup, alacağını temsil eden kıymetli evrakları forfaiter'e satarak iskonto ettirmekte kredili satışını paraya çevirebilmekte, ödenmeme riskinden tamamen kurtulmaktadır. Forfaiting işlemi genellikle hızlı ve basit olup, işlemleri için çok sayıda belge gerekmemektedir (Akgüç, 1998: 637-638).

Forfaiter alacak hakkını satın alan ve forfaiting işlemi konusunda uzmanlaşmış bir kuruluştur. Forfaiter, ihracatçının alacağını temsil eden poliçe veya senet gibi kıymetli evrakları rücusuz yani ticari veya politik riskler nedeniyle ödenmeme durumunda ihracatçıyı sorumlu tutmama koşuluyla satın almaktadır. Böylece kıymetli evrak bedellerinin herhangi bir nedenle ödenmemesi durumunda doğacak bütün riskleri forfaiter üstlenmiş olur. Tipik bir forfaiting işleminde dört taraf bulunmaktadır ve iş akışı aşağıdaki gibidir (Toroslu, 2000: 4957): 


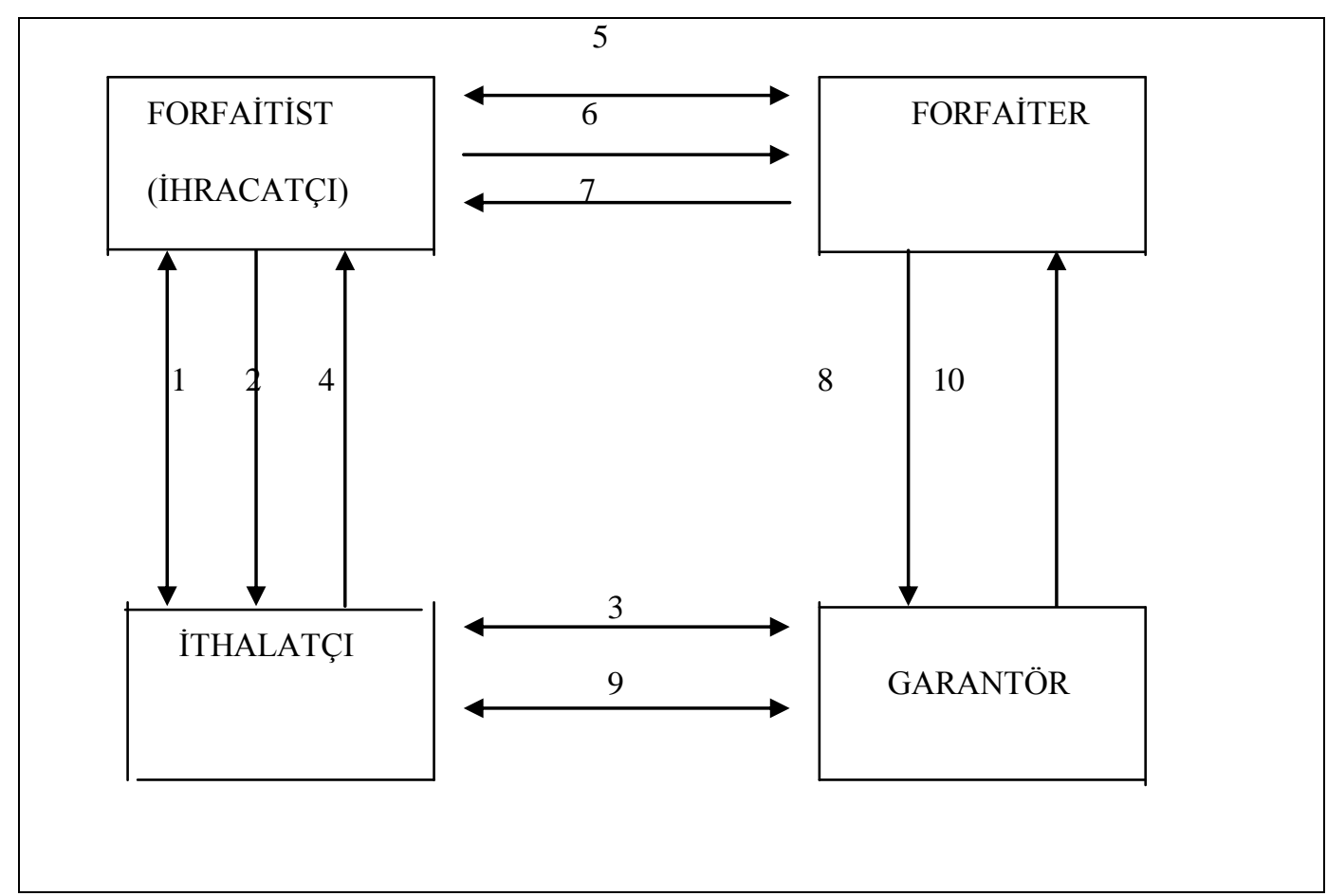

Şekil 1: Forfaiting İşlem Akış Şeması

Kaynak: Toroslu, 2000: 57

Forfaiting işleminin başlangıcı ihracatçı ile ithalatçı arasında bir satış sözleşmesi imzalanmasıdır ve daha sonra ihracatçı firma forfaiter ile anlaşmaktadır. Bazı durumlarda forfaiter ile ihracatçı satış işleminden önce de anlaşabilmektedir. İhracatçı imzalanan forfaiting sözleşmesine uygun olarak elindeki kıymetli evrakı forfaiter'e teslimiyle vadesinden önce ihracat ile ilgili alacaklarını tahsil ederek likiditesini arttırmış olmaktadır.

\subsection{Forfaiting İşlemlerinde Risk ve Maliyet Unsuru}

Forfaiting maliyetini etkileyen riskler, ticari risk, döviz transferi riski ve ülke riskidir. Ticari risk ithalatçı tarafindan üstlenilmektedir. Politik ve döviz transferi riski, ithalatçının ülkesinin kredi değerliliğine göre belirlenmektedir. Ülke riski arttıkça, iskonto oranı da yükselmektedir (Ceylan, 2003: 67). Forfaiterin satın alacağı senetler fazla kullanılmayan bir para birimi üzerinden olabilir. Bu durumda forfaiter bir kur riski ile karşı karşıyadır. Forfaiterin satın aldığı poliçeler kendi ülke parası cinsinden değilse forfaiterin kur riskini de maliyetine eklemesi uygun olacaktır.

İhracatçı orta ve uzun vadeli alacaklarını forfaitere satıp nakit para alabilmek için bir takım maliyetlere katlanmak zorundadır. İskonto oranı, yapılan iskonto işleminde uygulanan orandır. İskonto oranı, forfaiterin forfaiting taahhüdünde bulunduğu tarihteki piyasa faiz oranına bağlı olarak belirlenmektedir (Erdemol, 1992: 88). Forfaiting işleminde ihracatçı açısından maliyet unsurları faiz ve faiz riski, taahhüt ve opsiyon komisyonudur (Ceylan, 2003: 67).

Forfaiting işlemlerinde opsiyon süresi de söz konusu olmaktadır. Forfaiter incelemeler sonunda teklifi kesin olarak kabul ederse öne sürdüğü koşulların kabulü ya da reddi için 
ihracatçıya süre tanımaktadır. Teklifin kabulü için forfaiterin tanıdığg süre 48 saattir. Buna opsiyon süresi denir ve forfaiter bu süre için prim istemeyecektir. Eğer daha uzun süreler tanınıyorsa, bu durumunda ihracatçı forfaitere bir opsiyon primi ödeyecektir ve opsiyon komisyonu anlaşmanın başlangıcında ödenmektedir (Akgüç, 1998: 643).

Forfaiting finansmanında taraflardan biri olan ithalatçı açısından maliyet unsuru garanti ücretidir. Garanti ücreti, garanti verilen senet ya da bononun itibari değerinin belirli bir yüzdesidir. Garanti yüzdesi ithalatçı ve garantör arasında karşılıklı anlaşma ile belirlenmektedir. Forfaiter garanti belgesi istemediğinde riski üstlenmiş olmaktadır ve bu ithalatçının maliyetin azaltmaktadır (Ceylan, 2003: 73).

\section{TFRS 15 VE TMS 21 ÇERÇEVESINDE FORFAITING İ̧̧LEMLERİ VE MUHASEBESI}

Forfaiting sözleşmelerinde TMS 18 Hasılat standardı yürürlükten kaldırılması ile birlikte TFRS 15 Müşteri Sözleşmelerinden Hasılat standardı uygulamaya girmiştir. TFRS 15 Müşteri Sözleşmelerinden Hasılat standardı TMS 18 Hasılat standardını içerdiği gibi, TMS 18 standardında değinilmeyen hizmet geliri, sözleşme değişiklikleri gibi konularda yenilikler getirmektedir. Forfaiting işlemlerine ilişkin muhasebe uygulamalarının anlaş1labilmesi için aşağıda TFRS 15 ve TMS 21 standartları açıklanmaktadır.

\subsection{TFRS 15 Müşteri Sözleşmelerinden Hasılat}

$\mathrm{Bu}$ standardın amacı, müşteriyle yapılan bir sözleşmeden ortaya çıkan hasılatın finansal tablolarda raporlanmasında firmanın uygulayacağı ilkeleri düzenlemektir. Firmanın mal veya hizmetlerinin devri karşılığında kazanç üzerinden hasılatı finansal tablolara yansıtmasını düzenleyen standarttır (TFRS 15, Md: 2). Bu standardın uygulanabilmesi için karşı tarafın müşteri olması gerekmektedir. Müşteri, firmanın mal veya hizmetlerini bedeli karşılığında elde etmek amacıyla firma ile sözleşme yapan taraftır. Sözleşmenin bu standart kapsamında muhasebeleştirilebilmesi için gereken şartlar (TFRS 15, Md: 6- 9):

a) Sözleşme yazıl1, sözlü olarak onaylanmış ve ticari niteliktedir,

b) Mal veya hizmet için tarafların hakları ve ödeme koşulları tanımlanmıştır,

e) Müşteriye devredilecek mal veya hizmet karşılığındaki bedelin tahsili muhtemeldir.

Müşteri tanımında en önemli unsur, firmanın faaliyetlerinden mal ve hizmet elde etmek için sözleşme yapan bir kişilik olmasıdır. Müşteri ile yapılan sözleşmede firma mal ve hizmet vaadinde bulunmakta, müşteri ise buna karş1lık bir bedel ödemeyi taahhüt etmekte ve bunun sonucunda hak ve yükümlülük doğmaktadır (Özerhan vd, 2015: 197).

Standart aşağıdaki sözleşmelere uygulanmaz (TFRS 15, Md: 5):

a) TMS 17 Kiralama işlemleri kapsamındaki sözleşmeler, 
b) TFRS 4 Sigorta sözleşmeleri kapsamındaki sözleşmeler,

c) Finansal araçlar ve diğer sözleşmeye dayalı haklar veya yükümlülükler,

d) Aynı iş alanındaki firmalar arasında parasal olmayan değişimler.

TFRS 15' e göre, edim yükümlülüğü yerine getirildiğinde hasılat olarak muhasebeleștirme esastır. Edim yükümlülügüu zamana yayılmış olabileceği gibi bir anda da gerçekleştirilebilmektedir. Edim yükümlülügünün ne zaman yerine getirileceği sözleşmede belirtilmektedir.

Edim yükümlülüğ̈̈ kriteri esasen TFRS 15 standardının temel taşıdır. Gelirin tahakkuk etmesi, sözleşmenin edim yükümlülüklerinin yerine getirilmesine bağlıdır (Keskin ve Dinçer, 2015: 227).

Bir edim yükümlülüğü yerine getirildiğinde firma bu hasılat olarak finansal tablolara almaktadır. Firma işlem tutarını belirlemek için sözleşme hükümlerini dikkate almaktadır. İşlem tutarı, firmanın üçüncü şahıslar adına tahsil edilen tutarlar dışındaki, taahhüt ettiği mal veya hizmetleri müşteriye devretmesi karşılığında hak etmeyi beklediği tutardır (TFRS 15, Md: 46-47).

TFRS 15 standardı muhasebeleştirmede işlem fiyatını esas almaktadır. Gerçeğe uygun değer üzerinde muhasebeleştirilmeyip "işlem fiyatı" üzerinden kayıtlara alınmaktadır. İşlem fiyatı belirlenirken; değişken bedeller, paranın zamana değeri, parasal olmayan bedeller ve müşteriye yapılacak ödemelerin doğuracağı etkilere yönelik düzeltmeler göz önünde bulundurulmaktadır (Köse ve Çelikay, 2015: 28).

Bir sözleşme yapıldığında birçok maliyet ortaya çıkabilir. Firma için katlanılan maliyetler doğrudan taahhüt edilen yükümlülükle ilgili olabildiği gibi taahhüt edilen yükümlülüğü ifa edebilmek için dolaylı maliyetlere de katlanması gerekebilir (Calayoğlu ve Y1lmaz, 2016: 32).

Sözleşmede bir finansal bileşen varsa, işlem fiyatının belirlenmesinde taahhüt edilen bedelde paranın zaman değerinin etkisine göre düzeltme yapılmaktadır (TFRS 15, Md: 60). Sözleşmede önemli bir finansman bileşenin varlığının kabul şartları a) taahhüt edilen bedel ile taahhüt edilen mal veya hizmetin nakit satış fiyatı arasındaki fark b) müşteriye teslim edilen mal veya hizmetin zamanı ile tahsili arasında zaman olması ve ilgili piyasada geçerli faiz oranı olmasidır (TFRS 15, Md: 61).

TFRS 15 standard1, kuşkusuz tüm ülkelerde en fazla vergi kayıplarına neden olan, itinalı ve etik bir şekilde belirlenmesi gereken hasılatın doğru ve adil ölçülmesine büyük katkılar sağlayacaktır (Ataman ve Cavlak, 2017: 428).

\subsection{TMS 21 Kur Değişiminin Etkileri}

Firma yabancı para birimlerinde işlemler yapmak suretiyle faaliyetlerde bulunabilir. $\mathrm{Bu}$ standart, yabancı para işlemlerin finansal tablolara dahil edilmesini ve kullanılan para birimine çevrilişini ele almaktadır. Kullanılacak döviz kurları, döviz kurlarındaki değişiminin 
finansal tablolara üzerinde olan etkilerinin nasıl raporlanacağı düzenlenmektedir (TMS 21, Md: 1-2 ). Yabancı para bir işlem, aşağıdakileri kapsar (TMS 21, Md: 20):

(a) Yabancı para biriminden mal ve hizmetlerin alınıp satılması;

(b) Yabancı para biriminden kredi alınması veya borç verilmesi,

(c) Yabancı para biriminden varlık edinilmesi ile doğan yükümlülükler.

Yabancı para işlemi ile ilgili ilk muhasebeleştirme yabancı para birimindeki tutara geçerli kur uygulanarak, geçerli para biriminden muhasebe kaydına alınmaktadır (TMS 21, Md: 21).

Bir yabancı para işlemi ilk muhasebeleştirme sırasında; yabancı para birimindeki tutara, geçerli para birimi ile işlem tarihindeki yabancı para birimi arasındaki geçerli kur uygulanarak, geçerli para biriminden kaydedilir (Bozkurt, 2016: 471).

Finansal raporlama döneminde aşağıdaki işlemler gerçekleştirilir (TMS 21, Md: 23):

(a) Yabancı para kalemlerin kapanış kuru üzerinden geçerli para birimine çevrim işlemi gerçekleştirilir,

(b) Maliyet cinsinden ölçülen yabancı para birimindeki parasal olmayan kalemlerin işlem tarihindeki döviz kurundan geçerli para biriminden çevrim işlemi gerçekleştirilir,

(c) Gerçeğe uygun değerle ölçülen yabancı para birimindeki parasal olmayan kalemler ölçüldüğü tarihteki döviz kurundan geçerli para birimine çevrim işlemi gerçekleştirilir.

Kur farklarının muhasebeleştirilmesine ilişkin standardın, yabancı paraya dayalı işlemlerin muhasebeleştirilmesi ve raporlanması açısından tek başına yeterli olmadığı, diğer standartlarla birlikte uygulama alanı bulması gerektiği bir gerçektir (Ceran ve Ortakarpuz, 2013: 79).

\subsection{TFRS 15 ve TMS 21'e Göre Forfaiting İşlemleri}

“TMS 21 Kur Değişiminin Etkileri” standardı ağıllkkla kullanılan para birimini belirler ve yabancı para cinsinden işlemlerini ağırlıkla kullanılan para birimi cinsinden kaydetmektedir. Ağırlıkla kullanılan para birimi firmanın ăgırlıklı olarak nakitlerini oluşturduğu ve harcadığ 1 çevrenin para birimidir.

TMS 21'e göre ihracatçı ve forfaiter sözleşme işlemlerine ilişkin ilk muhasebe kayıtlarında işlem tarihindeki spot kuru kullanmaktadırlar. Spot kur hemen teslim halindeki geçerli olan döviz kurudur. Fakat çok dalgalı döviz kurlarında haftalık, aylık ortalama kurlardan yararlanılabilmektedir. Hem ihracatçı firma hem de forfaiter yabancı para işlemelerinin sonraki ölçümlerinde ise yine dönem sonundaki spot kuru esas almaktadırlar ve kur farkı kazanç ya da kayıpları kâr/zarar yansıtılmaktadır. Finansal tabloların çevriminde varlık ve yükümlülükler raporlama tarihindeki spot kur üzerinden çevrilmektedir. TMS 21 yürürlüğe girmeden önce ilk muhasebeleştirmede işlem tarihindeki kur ile kayıtlara alınmasına rağmen dönem sonu değerlemede Maliye Bakanlığı'nca belirlenen dönem sonu 
kur üzerinden işlem yapılarak kur farkları kâr/zarar hesabında muhasebeleştirilmektedir. Ayrıca, finansal tablo çevrimine ilişkin hükümler yer almamaktadır.

TFRS 15' e göre sözleşme taraflar arasında uygulanabilir haklar ve yükümlülükler yaratan anlaşmalardır. Forfaiting sözleşmelerinde taraflar ihracatçı ve forfaiter olup iki taraf arasında hukuken icra edilebilir hak ve yükümlülükleri doğuran bir sözleşme imzalanmaktadır. Sözleşmenin yükümlülüğü ihracatçının forfaiterden tahsil ettiği bedel karşılığında mal veya hizmetleri forfaiter firmasına devretme yükümlülüğüdür. Standart için en önemli unsurlardan biri edim yükümlülüğüdür. İhracatçı firma poliçeleri forfaiter firmasına vererek edim yükümlülüğünü yerine getirmektedir. Edim yükümlülüğü sözleşmede belirlenen malların veya hizmetlerin müşteriye transferi anlamına gelir. Mal veya hizmetin müşteriye transferi ile edim yükümlülüğü gerçekleşir ve gelir tahakkuk ettirilir. Forfaiting işlemlerinde mal ve hizmeti poliçeler oluşturmaktadır ve ihracatçı poliçeleri forfaitier firmasına teslim ederek edim yükümlülügüünü yerine getirmekte karş1lığında para tahsil etmektedir. Forfaiter firması da müşteri olarak poliçeleri satın almaktadır.

TFRS 15 yürürlüğe girmeden önce hasılatlardan vade farkının ayrıştırılmazken standartların uygulanmasıyla birlikte vade farkı tutarları peşin değerlerden ayrıştırılarak söz konusu olan tutarlar ait oldukları dönemde gider veya gelir hesabında muhasebeleştirilmektedir.

TFRS 15'e göre sözleşmede bir finansal bileşen varsa, taraflarca kararlaştırılan ödemelerin zamanlaması, müşteriye veya firmaya önemli bir fayda sağlıyorsa, firma işlem bedelini belirlerken taahhüt edilen bedelden paranın zaman değerinin hesaplanması esastır. Forfaiting sözleşmesindeki bedelin zaman değerinin hesaplanması gerekmektedir. Paranın zaman değeri, parasal bir tutarın belirli bir faiz oranından gelecek bir tarihteki değeridir.

Gelecekteki değer hesaplaması: Gelecekteki Değer(GD): Bugünkü Değer (BD+[Bugünkü Değer(BD)x Faiz Oranı(r)]

Para giriş ve çıkışlarının zaman içindeki dağılımı da değişik olabileceğinden paranın zaman değerini dikkate alarak para giriş ve çıkışlarını karşılaştırmak anlamlıdır (Cesur, 2006: 1): $\quad \mathrm{Pn}=\mathrm{P}_{0}(1+\mathrm{i})^{\mathrm{n}}$

$\mathrm{Pn}=$ Dönem sonunda elde edilecek anapara + faiz toplamı.

$\mathrm{P}_{0}=$ Dönem başında yatırılan para

$\mathrm{i}=$ Faiz oranı

$\mathrm{n}=$ Dönem sayıs1

\subsection{Forfaiting İşlemlerinin Muhasebeleştirilmesi}

Forfaiting işlemleri, orta ve uzun vadeli yatırım malı satışlarında ödemeler genellikle 6'şar aylık taksitler halinde yapılmaktadır. Ödemeler daha çok 5 y1l vadeli ve 10 eşit taksitte yapılmakta olup, poliçe ya da bonolar genellikle her bir ödeme için ayrı ayrı düzenlenmektedir. 
TMS/TFRS'yi uygulayan ve forfaiting hizmeti alan firmalar açısından muhasebe kayitları 26.12.1992 tarih ve 21447 sayılı Resmi Gazete'de yayınlanan 1. Srra No'lu Muhasebe Sistemi Uygulama Genel Tebliği (MSUGT) ile zorunlu hale getirilen Tekdüzen Muhasebe Uygulamasına göre yapılması gerekmektedir.

Forfaiting işlemi yapan finans kuruluşları, ülkemizde Bankacılık Düzenleme ve Denetleme Kurumu (BDDK) bünyesindeki yönetmelik ve tebliğlerle çalş̧ma esasları belirlenmiştir, TMS/TFRS Seti'ne ve BDDK tarafindan yayımlanan Tekdüzen Hesap Planı'na tabidirler. BDDK tarafindan 24 Aralık 2013 tarih 28861 sayılı Resmi Gazete'de "Finansal Kiralama, Faktoring ve Finansman Şirketlerince uygulanacak Tekdüzen Hesap Planı yayımlanmışıtr. Tekdüzen Hesap Planı, aşağıdaki gruplardan oluşmaktadır (http://www.resmigazete.gov.tr/eskiler/2013/12/20131224-16.htm):

0 Dönen Değerler

1 Ana Faaliyetlerden Alacaklar

2 Yatırım Amaçlı Değerler ve Diğer Aktifler

3 Bankalardan Kullanılan Krediler ve Diğer Yabancı Kaynaklar

4 Özkaynaklar

5 Ana Faaliyet Gelirleri

6 Finansman Giderleri

7 Faaliyet Dışı Gelirler

8 Faaliyet Giderleri ve Diğer Giderler

9 Bilanço Dışı Hesaplar

Söz konusu Tekdüzen Hesap Planı'nda bulunan hesaplar, Türk parası ve yabancı para olarak ikiye ayrılmıştır. Türk parası ve yabancı para işlemler için çalışan hesaplar, 022 Yurtiçi Bankalar T.P, 023 Yurtiçi Bankalar Y.P. şeklinde büyük defter seviyesinde belirlenmiştir. Hesapların son hanesi çift sayı ise Türk Parası hesapları, tek sayı ise yabancı para hesapları olarak tanımlanmıştır. Yabancı para olarak yer alan hesaplar, yabancı para işlemlerle ilgili tutarların muhasebeleştirildiği hesaplardır. Söz konusu hesaplardaki yabancı para kalanı ilgili TMS/TFRS Seti kapsamında dönem sonlarında değerlemeye tabi tutulmakta ve değerleme farkları ilgili kâr/zarar hesaplarında muhasebeleştirilmektedir. Yabancı para işlemlerden elde edilen yabancı para faiz, komisyonlar, işlem tarihindeki kurdan Türk parasına çevrilmekte ve ilgili yabancı para kâr/zarar hesaplarında muhasebeleştirilmektedir. Söz konusu gelirler, yabancı para yerine Türk parası üzerinden tahsil edilmiş olsa da ilgili yabancı para, kâr-zarar hesaplarında muhasebeleştirilmektedir. 


\subsection{1. Örnek Uygulama}

Aşağıda yer alan forfaiting sözleşmelerine ilişkin uygulama örneği muhasebe kayıtları, ihracatçı firma tarafindan Muhasebe Standartları Uygulama Genel Tebliği tarafindan yayımlanan Tekdüzen Hesap Planı doğrultusunda, forfaiter firması tarafindan Bankacılık Düzenleme ve Denetleme Kurumu tarafindan yayımlanan Tekdüzen Hesap Planı doğrultusunda gerçekleştirilmiştir. Örnek uygulama sorusu Ceylan (2003) referans alınarak hazırlanmıştır.

Hisse senetleri borsada işlem gören A firması 01.01.2018 tarihinde, ABD'de bulunan $\mathrm{X}$ firmasına 5 yıl vadeli olarak peşin değeri $\$ 2.500 .000$ tutarında makine ihracatını gerçekleştirmiştir. Toplam tutarın 10 taksitle ödenmesi söz konusu olup yıllık faiz oranı $\% 8$ olarak belirlenmiştir. A firması aynı zamanda forfaiter ile söz konusu satışına istinaden aynı faiz oranı ve tutardaki alacak hakkını satma konusunda sözleşme imzalamışlardır. Sözleşme komisyonu oranı \% 5 olup, sözleşme şartları;

Malın satış fiyatı: $\$ 2.500 .000$

Vade $\quad: 5$ yıl

Ödeme şekli : İlk ödemenin malın tesliminden 6 ay sonra olmak üzere 6 ayda bir ödenecek 10 poliçe ile

Kararlaştırılan faiz oranı: \% 8 (yıllık)

Gecikme süresi $\quad$ : 3 gün

Komisyon tutar1 $\quad: \$ 2.500 .000 \times \% 5=\$ 125.000$

A firması forfaiterden poliçelerin bedelini döviz olarak tahsil etmiştir.

Burada da taksitler dönem sayısına bölünerek eşit anapara taksitleri bulunmaktadır.

Anapara + faiz tutan olarak toplam geri ödeme taksidi;

Gelecekteki Değer = Bugünkü Değer x $(1+\mathrm{i})^{\mathrm{n}}$ formülü ile hesaplanmaktadır. Hesaplanan toplam geri ödeme taksitleri aşağıdaki tabloda yer almaktadır;

Anapara Vade Anapara Toplam Geri Ödeme

Taksiti Bakiyesi (Faiz + Anapara)

(\$)

(n)

(\$)

\begin{tabular}{llll}
\hline- & & $\$ 2.500 .000-$ & - \\
$250.000-$ & 1 & $2.250 .000-$ & $260.000-(1)$ \\
$250.000-$ & 2 & $2.000 .000-$ & $270.400-(2)$ \\
$250.000-$ & 3 & $1.750 .000-$ & $281.216-$ \\
$250.000-$ & 4 & $1.500 .000-$ & $292.465-$
\end{tabular}




\begin{tabular}{llrl}
$250.000-$ & 5 & $1.250 .000-$ & $304.163-$ \\
$250.000-$ & 6 & $1.000 .000-$ & $316.330-$ \\
$250.000-$ & 7 & $750.000-$ & $328.983-$ \\
$250.000-$ & 8 & $500.000-$ & $342.142-$ \\
$250.000-$ & 9 & $250.000-$ & $355.828-$ \\
$250.000-$ & 10 & - & $370.061-$ \\
\hline$\$ 2.500 .000-$ & & $\$ 3.121 .588-$ \\
\hline
\end{tabular}
(1) $\$ 250.000 *[+(0.08 * 6 / 12)]^{1}=\$ 260.000-$
(2) $\$ 250.000 *[+(0.08 * 6 / 12)]^{2}=\$ 270.400-$

\section{İhracatcı Firmanın Muhasebe Kavitları}

-İhracatçı firma \$2.500.000 tutarındaki ihracat bedelinin satışı kur: 3,80 TL iken muhasebe kaydi;

Satışın peşin tutarı: $\$ 2.500 .000$ x $3,80=9.500 .000 \mathrm{TL}$

Vadeli satı̧ tutarı: $\$ 3.121 .588 \times 3,80=11.862 .034 \mathrm{TL}$

Vade fark1 tutar1: $\$ 3.121 .588-\$ 2.500 .000=\$ 621.588 \times 3.80=2.362 .034 \mathrm{TL}$

K1sa vadeli tutar:[ $\$ 500.000$ (anapara) $+\$ 30.400$ (faiz)] x 3,80 $=2.015 .520$ TL ilk iki taksit ve anapara tutarıdır.

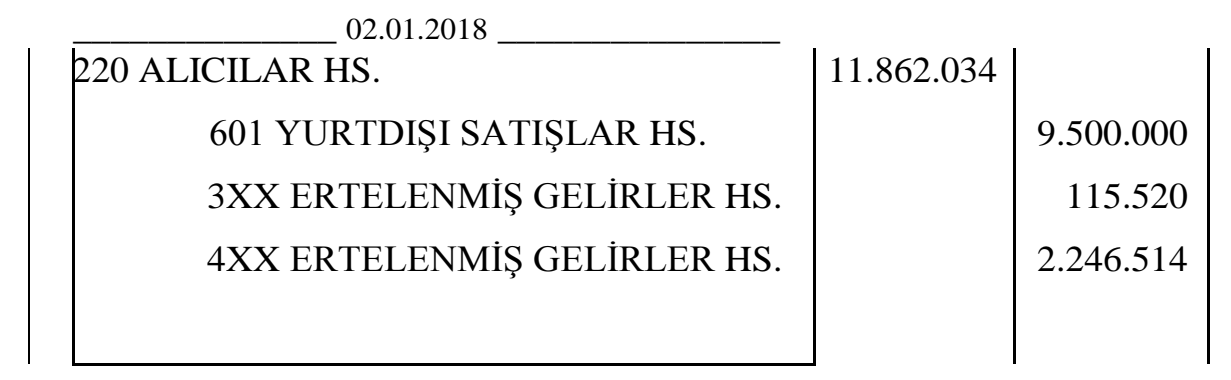

Yukarıdaki kayıtta görüldüğü üzere \$30.400 tutarındaki kısa vadeli faz tutarının TL tutarı (\$30.400x3.80) 115.520 TL'dir. 3XX Ertelenmiş Gelirler hesabı yerine ve 4XX Ertelenmiş Gelirler hesabı Tekdüzen Hesap Planı'nda tanımlanmamış olup revizyona ihtiyaç duyulmaktadır. Ayrıca, satış uzun vadeli olduğundan "Duran Varlıklar" grubunda olan 220 Alıcılar hesabında muhasebeleştirilen tutar bir yıla indiğinde "Dönen Varlıklar" grubuna aktarılarak 120 Alıcılar hesabında muhasebeleştirilmektedir. 
-Poliçelerin ithalatçı firma tarafindan kabul edildiğinde muhasebe kaydı;

02.01 .2018

\begin{tabular}{|c|c|c|}
\hline 121 ALACAK SENETLERİ HS. & 2.015 .520 & \\
\hline 221 ALACAK SENETLERİ HS. & 9.846 .514 & \\
\hline 220 ALICILAR HS. & & 11.862 .034 \\
\hline
\end{tabular}

Yukarıdaki muhasebe kaydında poliçelerin bir yıllık kısmına ait anapara ve faiz tutarı hesaplanarak 121 Alacak Senetleri hesabına kalan tutar ise uzun vadeli poliçe olduğundan 221 Alacak Senetleri hesabında muhasebeleştirilmektedir.

-Poliçelerin forfaiting firmasına devredilerek poliçe tutarının forfaiting firmasından tahsil edilmesinin muhasebe kaydr;

02.01.2018

\begin{tabular}{|c|r|r|}
\hline 102 BANKALAR HS. & 9.500 .000 & \\
121 ALACAK SENANSMAN GIDERİ & 2.362 .034 & \\
221 ALACAK SENETLERİ HS. & & 2.015 .520 \\
& & 9.846 .514 \\
& & \\
\hline
\end{tabular}

-Forfaiting firmasına komisyon bedelinin ödenmesi;

Komisyon tutar1: $\$ 2.500 .000 \times \% 5=\$ 125.000 \times 3,80=475.000 \mathrm{TL}$

02.01.2018

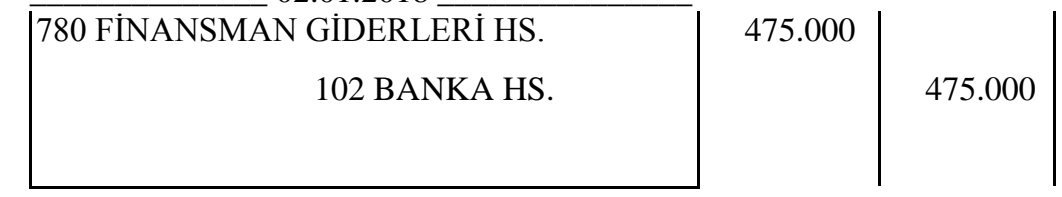

Poliçeler yapılan forfaiting anlaşması gereği forfaiting hizmeti veren kuruluşa teslim edilmiştir.

-30 Haziran 2018 tarihinde dönem sonu itibariyle vade farkı tutarının ilgili hesaba aktar1mas1 (\$ kur: 4,06TL):

Forfaiting sözleşmesinde ilk taksit 6 ay sonra ödenecektir İlk taksit $\$ 260.000$ (anapara+faiz) - \$250.000(anapara) $=\$ 10.000$ ilk 6 aylık vade farkı tutarıdır.

6 aylık vade farkının 30.06.2018 tarihli kayıtlı TL tutar $=\$ 10.000 \times 4.06=40.600 \mathrm{TL}$

6 aylik vade farkının 02.01.2018 tarihli kayıtlı TL tutar $=\$ 10.000 \times 3,80=38.000 \mathrm{TL}$ 
Kur fark1 TL tutarı $=40.600 \mathrm{TL}-38.000 \mathrm{TL}=2.600 \mathrm{TL}$

30.06.2018

\begin{tabular}{|}
382 ERTELENMIŞ GELIRLER HS. \\
612 DİĞER İNDIRIMLER HS. \\
01 İHR. DOĞAN KUR FARKI GİDERİ HS. \\
642 FAİZ GELİRLERİ HS
\end{tabular}

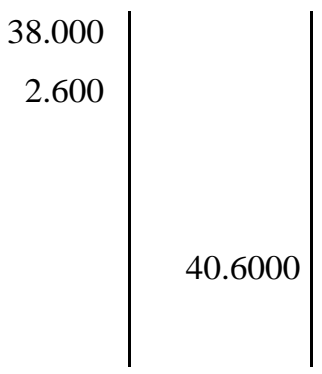

Yabancı paralı işlemlerde kurun değişmesinden dolayı satışla aynı cari faaliyet döneminde gerçekleşen kur farkları lehte ise 601 Yurt dışı satışlar ana hesabı içinde alt hesap tanımlanarak ihracattan doğan kur farkı hesabı olarak takip edilmektedir. Aleyhte kur farkları ise 612 Diğer İndirimler ana hesabı içinde ihracattan doğan kur farkı gideri olarak borç kaydedilmektedir. Gelecek yılda ise, lehte gerçekleşen kur farkları 646 Kambiyo Kârları hesabına, aleyhte gerçekleşen kur farkları ise, 656 Kambiyo Zararları hesabına kaydedilmektedir. İlgili ayda gider kaydedilmek amacı ile geçici hesaba kaydedilmiş olan faiz ve komisyon tutarına da değerleme yapmak gerekmektedir.

\section{Forfaiter Firmasının Muhasebe Kayıtları}

Örnek uygulamada BDDK'nın yayımladığı Finansal Kiralama, Faktoring ve Finansman firmaları için yayınlanmış olan muhasebe uygulamalarında yararlanılarak Tekdüzen Hesap Planı doğrultusunda muhasebe kayıtları gerçekleştirilmektedir. Tebliğ defteri kebir düzeyinde açılmış hesaplar için ihtiyaç halinde yardımcı ve alt hesaplar açabilmesine izin vermektedir ve forfaiting için ana hesap bazında hesap tanımlanmamıştır. Orta ve uzun vadeli faktoring işlemleri ile forfaiting işlemleri arasında benzerlik söz konusudur. Forfaiting işlemlerinin faktoring işlemlerinden fark1 vadenin uzun olmas1, alacağın banka garantili senede bağlı olmasıdır. Örnek uygulamada forfaiting işlemleri için ayrıca defteri kebir düzeyinde hesap kodu tanımlanmadığından muhasebe kayıtlarında ana hesaplar bazında işlemlerin benzerliğinden dolayı orta ve uzun vadeli faktoring işlemleri ile ilgili ana hesaplardan yararlanılmaktadır. kayd1:

-Forfaiter tarafından sözleşmeye konu olan poliçelerin nazım hesaplarda muhasebe

02.01 .2018

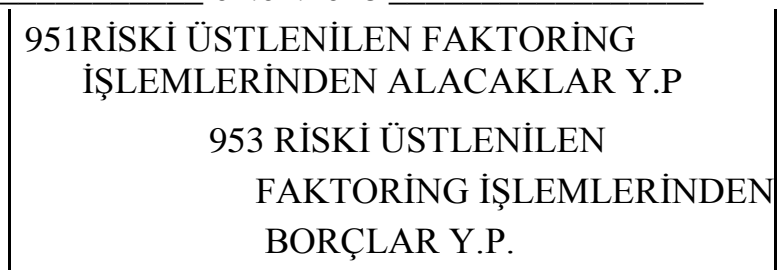


-Forfaiter tarafından sözleşmeye konu komisyon tutarının tahsilinin muhasebe kaydı, Komisyon tutar1: $\$ 2.500 .000 \times \% 5=\$ 125.000 \times 3,80=475.000 \mathrm{TL}$ 02.01 .2018

\begin{tabular}{|c|}
2911 EFEKTİF DEPOSU YP \\
293 EFEKTIF VAZIYETİ YP \\
703 DİĞER FAKTORİNG \\
ALACAKLARINDAN ALINAN \\
ÜCRET VE KOMİSYONLAR YP
\end{tabular}

\begin{tabular}{r|r|}
125.000 & \\
475.000 & \\
125.000 \\
475.000
\end{tabular} \mid

Nakit olan yabancı ülke paralarına efektif olarak adlandırılırken, yabancı ülke parası ile ödeme yapılmasına imkan sağlayan hesap ve belgeler döviz olarak isimlendirilmektedir. İşlemler yabancı para birimi üzerinden tek numaralı hesaplarda muhasebeleştirilmektedir (Sevilengül, 2001: 208-209).

Alınan efektif tutarı 293 Efektif Vaziyeti Y.P. hesabının alacağı ile 011 Efektif Deposu Y P hesabının borcunda muhasebeleştirilmektedir. Satılan efektif tutarı ise, 293 Efektif Vaziyeti Y.P. hesabının borcunda ve 011 Efektif Deposu YP hesabının alacağında muhasebeleştirilmektedir. 292 Efektif Alım/Satım TP hesabı alınan veya satılan efektiflerin Türk parası karşılıklarının kaydedildiği bir hesaptır. 293 Efektif Vaziyeti Y.P. hesabın yabancı para üzerinden kalanı ile 292 Efektif Alım/Satım T.P. hesabının Türk parası üzerinden kalanı işlem kuru üzerinden eşit olması gerekmektedir.

-02.01.2018 tarihinde forfaiter tarafından ihracatçıdan satın alınan poliçelere ilişkin muhasebe kaydı ve müşteriye ödemenin yapılması:

02.01 .2018

\begin{tabular}{|l|}
131 ORTA VE UZUN VADELİ \\
FAKTORİNG ALACAKLARI YP \\
293 EFEKTİF VAZIYETİ YP \\
294 DÖVİZ ALIM/SATIM HESABI TP \\
011 EFEKTİF DEPOSU YP \\
292 EFEKTİF ALIM/SATIM HS. TP \\
295 DÖVİZ VAZIYYTİ YP \\
393 ALACAKLI GEÇICİ HESABI YP
\end{tabular}

\begin{tabular}{r|r}
3.121 .588 & \\
2.500 .000 & \\
9.500 .000 & \\
2.500 .000 \\
9.500 .000 \\
2.500 .000 \\
621.588
\end{tabular} \mid


Forfaiter ihracatçı firmaya sözleşme şartlarına uygun olarak \$2.500.000'1 ödemektedir. Yukarıdaki muhasebe kaydında görüldüğü üzere yapılan ödeme ile senet tutarı arasındaki fark için 393 Alacaklı Geçici Hesaplar YP kullanılmaktadır. Ödeme yabancı para üzerinden yapılmayıp Türk Lirası üzerinden gerçekleştirilmiş olsaydı 011 Efektif Deposu YP hesabı yerine 010 Kasa Hesabı TP kullanılacaktır.

-30.06.2018 dönem sonunda forfaiting işlemine ilişkin ilk taksit tutarını ifade eden poliçenin tahsili;

30.06.2018

025 YURTDIŞI BANKALAR YP

131 ORTA VE UZUN VADELI

FAKTORİNG ALACAKLARI YP

Yukarıdaki muhasebe kaydında görüldüğü üzere, forfaiter ithalatçıdan ilk senet tutarını yabancı para üzerinden tahsil etmiş bulunmaktadır.

-30.06.2018 dönem sonunda forfaiting işlemine ilişkin ilk taksit tutarının faize ilişkin olarak, forfaiter tarafindan faizin ilgili döneme ait olan kısmı faiz gelirleri hesabında muhasebeleştirilmektedir:

Forfaiting işlemine ilişkin ilk taksidin faiz tutarı olan $\$ 10.000$ 'dir. 30.06 .2018 tarihi itibariyle \$ kur: 4,06 TL'dir. TL Faiz Tutarı: $\$ 10.000$ x 4,06 $=40.600$ TL

30.06.2018

393 ALACAKLI GEÇİCI HESAP YP

294 DÖVİZ ALIM/SATIM HESABI TP

295 DÖVIZZ VAZIYYETİ HESABI YP

531 ORTA VE UZUN VADELİ

FAKTORING ALACAKLARINDAN

ALINAN FAİLLER YP

Forfaiting işlemi ile ilgili alınan faizler "5 Ana Faaliyet Gelirleri" hesap grubu içinde yabancı para işlemleri ile ilgili olduğundan 531 Orta ve Uzun Vadeli Faktoring Alacaklarından Alınan Faizler Y.P hesap grubu içinde alt hesaplarda takibi mümkündür. Dönemsellik ilkesi gereğince, 393 Alacaklı Geçici Hesaplar' da kayıtlı olan yabacı para tutarı üzerinden faiz tutarı ilgili döneme gelindiğinde faiz gelirleri hesabına aktarılacaktır. 
-30.06.2018 dönem sonunda forfaiting işlemine ilişkin ilk taksit tutarının tahsili nedeniyle söz konusu poliçenin nazım hesaplardan yapılması gereken muhasebe kaydı;

30.06 .2018

\begin{tabular}{|c|}
953 RISKİ ÜSTLENILEN \\
FAKTORING İŞLEMLERINDEN \\
BORÇLAR Y.P \\
951RİSKİ ÜSTLENILEN \\
FAKTORING IŞLEMLERINDEN \\
ALACAKLAR Y.P
\end{tabular}

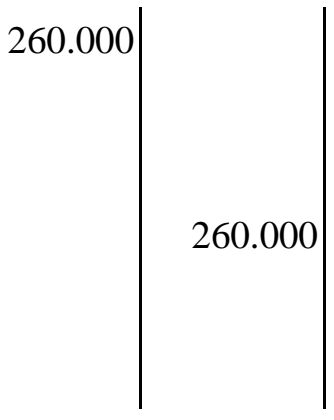

Yukarıdaki muhasebe kaydında forfaiter ilk taksit tutarını tahsil ettiğinden dolayı nazım hesaplarda kayıtlı olan bu ilk taksit tutarı ters kayıt ile muhasebe kaydından çıkarılmaktadır.

\section{SONUÇ}

Orta vadeli finansman tekniği olan forfaiting günümüzde her sektörde kullanılmaya başlanmıştır. Ülkemizde yaygın olarak kullanılmamakla birlikte dünyada daha fazla kullanılan bu tekniğin Türkiye'nin dünya ülkeleri ile ekonomik ilişkilerinin daha da artması ve piyasada rekabet için bu ve benzer tekniklerin kullanımının gerekliliği kaçınılmazdır.

Ülkemizde forfaiting tekniğinin yaygın kullanımına katkı sağlamak, uygulamasının tanınırlığını arttırmak amacıyla bu çalışma gerçekleştirilmiştir.

Çalışmada, forfaiting işlemleri alternatif finansman tekniği arayışında olan firmalar açısından değerlendirilmiş, forfaiting sözleşmesindeki tarafların ölçme ve muhasebeleştirmede tabi oldukları TFRS 15 ve TMS 21 standartlar hakkında bilgi verilerek örnek uygulama bu standartlar çerçevesinde muhasebe kaydına alınmıştır. Uygulama örneğindeki forfaiter ve hisse senetleri borsada işlem gören ihracatçı firma TMS/TFRS Seti'ne tabi olduğundan aynı usul ve esaslar çerçevesinde muhasebeleştirme gözlemlenmektedir. Fakat, tarafların muhasebe kayıtlarını tutmak zorunda oldukları hesap planları farklıdır. İhracatçı firmanın muhasebe kayıtları tabi olduğu TMS/TFRS Seti ve MSUGT'de bulunan Tekdüzen Hesap Planı doğrultusunda gerçekleştirilmiştir.

Forfaiter muhasebe kayıtlarında KGK tarafindan yayımlanan TMS/TFRS Setine tabi olmasına rağmen BDDK tarafından yayımlanan Tekdüzen Hesap Planı'na tabidir. Forfaiter muhasebe kayıtlarını Türk Parası ve Yabancı Para olarak gerçekleştirmektedir. Yabancı para işlemlerden elde edilen yabancı para faiz, komisyon ve gelirler, işlem tarihindeki kurdan Türk parasına çevrilmekte ve ilgili yabancı para kâr/zarar hesaplarında muhasebeleştirilmektedir. Aynı şekilde gelirler yabancı para yerine Türk parası üzerinden tahsil edilse bile, ilgili yabancı para kâr/zarar hesaplarında muhasebeleştirilmektedir.

TFRS 15 ve TMS 21 standartlarına tabi olan forfaiter ve ihracatçı firmanın forfaiting sözleşmesine ilişkin muhasebe kayıtları: 
-Sözleşmedeki işlem fiyatı üzerinden edim yükümlülüğün yerine getirilmesi ile ilk muhasebeleştirme gerçekleştirilmektedir,

-Vade farkları ayrıştırılarak muhasebeleştirilir,

-Gelirler gerçekleştiği dönemlerde gelir hesaplarına kaydedilir,

-Faiz ve benzeri giderler doğduğu dönemde gider kaydedilir,

-Yabancı para işlemler, ilk muhasebeleştirmede işlem tarihindeki spot kur üzerinden geçerli para birimine çevrilir,

-Yabancı para işlemler izleyen dönemlerde kapanış kurundan çevrilir ve kur farkları kâr/ zararda muhasebeleştirilir.

-Finansal tabloların çevriminde ise, varlık ve yükümlülükler raporlama tarihindeki spot kur üzerinden çevrilmektedir. Gelir, gider ve özkaynak kalemleri işlem tarihlerindeki döviz kurları üzerinden çevrilmektedir.

Ülkemizde uzun süredir uygulamadaki MSUGT doğrultusunda forfaiting işlemlerine ilişkin ölçüm ve muhasebe esasları TMS/TFRS Seti muhasebe kayıtlarından farklılık göstermektedir. Bu farklılıklar:

-İlk muhasebeleştirme satış fiyatı üzerinden mal teslimi ile gerçekleştirilmektedir,

-Vade farkı ayrıştırılmadan muhasebe kaydına alınmaktadır.

-Yabancı para cinsinden parasal kalemlerin çevrimi Maliye Bakanlığı'nın belirlediği kur üzerinden gerçekleştirilmektedir.

-Finansal tabloların çevriminde kullanılacak döviz kuru ile ilgili herhangi bir hüküm yer almamaktadir.

Sonuç olarak, ekonomide çok önemli rol üstlenen alternatif finansman tekniklerinden biri olan forfaiting işlemlerinin muhasebeleştirilmesi forfaiter ve ihracatçı açısından yürürlükteki standartlar doğrultusunda gerçekleştirilmiştir. Rekabet yoğunluğundan dolayı ihracatçının likidite sıkıntısına çözüm bulmada yararlanabileceği orta ve uzun vadeli finansman tekniği olan forfaiting işlemlerine dikkat çekilerek muhasebe uygulamaları hususunda konuya ilgi duyan sektör ve akademi dünyasına katkı sağlaması beklenmektedir. Daha sonraki çalışmalarda forfaiting işlemlerinin BOBİ FRS açısından ve ithalatçı açısından değerlendirmesinin ele alınması önerilmektedir.

\section{KAYNAKLAR}

Akgüç, Ö. (1998). Finansal Yönetim, 7. Baskı, Muhasebe Enstitüsü Yayını, İstanbul.

Aygün, D. (2014). "TMS 18 Hâsılat ve TMS 2 Stoklar Standartlarına göre Forfaiting İşlemleri ve Muhasebeleştirilmesi”, Yönetim ve Ekonomi Araştırmaları Dergisi, Sayı:23, 206227. 
Ataman, B. - Cavlak, C. (2017). “TFRS 15 Müşteri Sözleşmelerinden Hasılat: Temel İlkelerin İncelenmesi ve Bir Uygulama", Marmara Üniversitesi İktisadi ve İdari Bilimler Dergisi, Cilt: 39, Sayı: 2, 403-428.

Berk, N. (1999). Bankacılı̆̆ın Dışa Açılması ve Dış Kredi İlişkileri, Yapı Kredi Bankası Yayınlar1 No:4, İstanbul.

BDDK, Bankacılık Düzenleme ve Denetleme Kurumu, https://www.bddk.org.tr, [Erişim Tarihi: 02.01.2018].

Bozkurt, O. (2016). "TMS 21 Kur Değişiminin Etkileri Standardının Uygulaması ve Finansal Tablolara Yansıması", Bartın Üniversitesi İktisadi ve İdari Bilimler Fakültesi Dergisi, Cilt. 7, Sayı: 14, 465-482.

Calayoğlu, İ. - Yılmaz, R. (2016). “TFRS 15'e Göre Yazılım Sektöründeki Sözleşmelerin Hasılatının Hesaplanması ve Tanınması" PESA Uluslararası Sosyal Araştırmalar Dergisi, Sayı: 2 (2), 18-42.

Ceran, Y. - Ortakarpuz, M. (2013). "Kur Farklarının Muhasebe Uygulamaları ve Türkiye Muhasebe Standartları Kapsamında İncelenmesi”, Kahramanmaraş Sütçü İmam Üniversitesi İktisadi ve İdari Bilimler Fakültesi Dergisi, Cilt: 3, Sayı: 2, 65-80.

Cesur, A. M. (2006). Proje Değerlendirme Yöntemleri ve Kullanılan Enstrümanlar, Ankara.

Ceylan, A. (2003). Finansal Teknikler, 5. Baskı, Ekin Kitabevi, Bursa.

Dikmen, A. A (1992). "Forfaiting Risk ve Riskten Korunma", Ankara Üniversitesi, Siyasal Bilgiler Fakültesi Dergisi (Bedri Gürsoy’A Armağan), Cilt. 47, Sayı. 3-4, 113-122.

Erdemol, H. (1992). Bankalarda Dış Ticaret İşlemleri ve Uygulama, Akbank Yayınları, İstanbul.

Gürsoy, Y. (2005). Dış Ticaret İşlemleri Muhasebesi, Ekin Kitabevi, Bursa.

Keskin, A. İ., Dinçer, B. (2015). "UFRS 15 Müşteri Sözleşmelerinden Elde Edilen Hasılat Standardının İncelenmesi ve Telekomünikasyon Sektörüne İlişkin Bir Uygulama”, Maliye Finans Yazıları Dergisi, Sayı: 103, 219-247.

Köse, T., Çelikay, Ş. (2015). "Yeni Hasılat Standardı ve Getirdiği Değişiklikler” Mali Çözüm Dergisi, Ocak-Şubat, Sayı: 127, 1-44.

Özdemir, Z. (2005). "Dış Ticaret Finansman Tekniklerinden Faktoring ve Forfaiting İşlemleri”, Kocaeli Üniversitesi Sosyal Bilimler Enstitüsü Dergisi, Say1:10/2, 194-224.

Özerhan, Y. - Marşap, B., Yanık, S. S. (2015). "IFRS 15 Müşterilerle Yapılan Sözleşmelerden Doğan Hasılat Standardının İrdelenmesi”, Muhasebe Bilim Dünyası, Sayı: 17(2), 193 226. 
MSUGT, 1 Sira No'lu Muhasebe Sistemi Uygulama Genel Tebliği, http://www.resmigazete.gov.tr, (15.01.2018).

Resmi Gazete, http://www.resmigazete.gov.tr/eskiler/2013/12/20131224-16.htm, (.01.2018).

Sevilengül, O. (2001). Banka Muhasebesi, 3. Bask1, Gazi Kitabevi, Ankara.

TMS 21 (2018). Kur Değişiminin Etkileri, http://kgk.gov.tr, (10.01.2018).

TFRS 15 (2018). Müşteri Sözleşmelerinden Hasılat, http://kgk.gov.tr, (15.02.2018).

Toroslu, M.V. (2011). Hukuksal ve Finansal Açıdan Forfaiting, Adalet Yayınevi, Ankara.

Toroslu, M. V.(2000). Çağdaş Finansal Teknikler, Beta Yayıncılık, İstanbul. 